\title{
Defective monocyte phagocytic function as a possible genetic marker for rheumatic susceptibility
}

Mostafa Kamal Badr El-Din,' Ahmed Abdel-Salam Madkour, ${ }^{2}$ Omneya M.K. Badr El-Din, ${ }^{3}$ Eman A. Rashwan ${ }^{4}$ and Raouf S. Bahr ${ }^{5}$

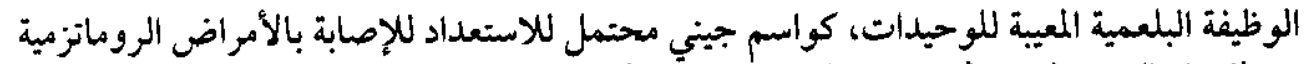

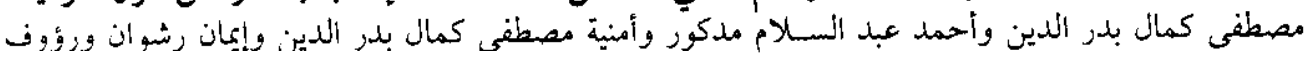

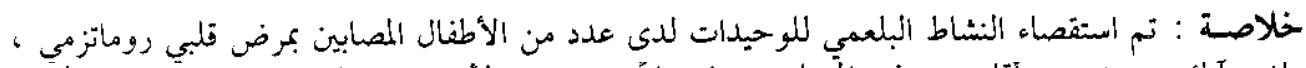

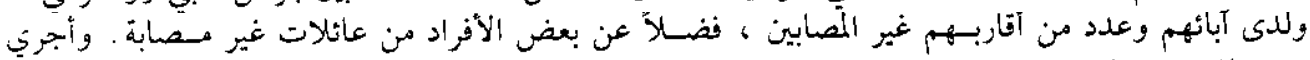

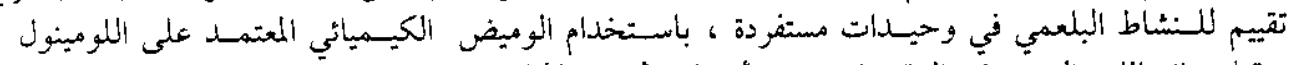

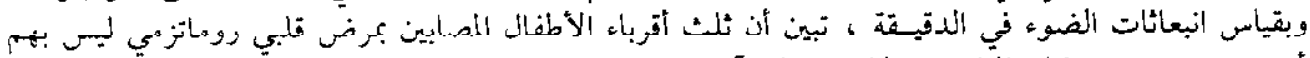

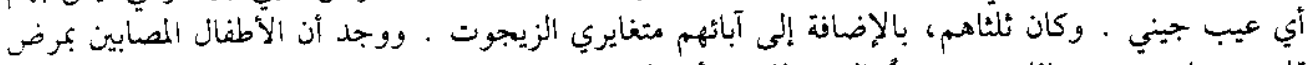

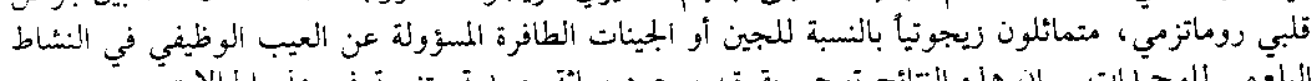

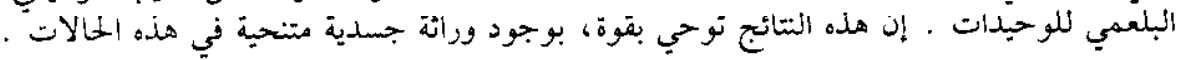

ABSTRACT The activity of the monocyte phagocytic system in children with rheumatic heart disease (AHD), their parents, their normal siblings and in non rhoumatic families was investigated. Phagocytic activity of isolated monocytes was assessed using luminol-dependent chemiluminescence. The count per minute of emitted light was measured before and after stimulation with zymosan solution. The results indicate that one-third of the siblings of children with RHD were genetically free while two-thirds, as well as the parents, were heterozygous, and that children with RHD were homozygous for (a) mutant gene(s) responsible for the defective function of the monocyte phagocytic system. The findings are strongly suggestive of autosomal recessive inheritance.

Une déficience de la fonction phagocytaire des monocytes comme marqueur génétique éventuel de la sensibilité aux rhumatismes

RESUME L'activité du système des phagocytes mononuclés a été examinée chez des enfants atteints de cardiopathie rhumatismale, chez leurs parents, chez leurs frères et soeurs normaux et dans un groupe de sujets n'ayant aucun antécédent familial de cardiopathie rhumatismale. L'activité phagocytaire des monocytes isolés a été estimée à l'aide de la chimioluminescence accentuée par le luminol. L'éllission de lumière par minute a été mesurée avant ct apròs stimulation par solution de zymosan. Les résultats ont indiqué qu'un tiers des frères et soeurs des enfants atteints de cardiopathie rhumatismale étaient homozygotes normaux tandis que les deux autres tiers ainsi que leurs parents étaient hétérozygotes, et que les enfants atteints de cardiopathie rhumatismale étaient homozygotes pour un(des) gène(s) mutant(s) responsable(s) de la fonction déficiente du système des phagocytes mononucléés. Ces résultats font penser à une hérédité autosomique récessive.

'Emeritus Protessor of Paediatrics; ${ }^{2}$ Professor of Paediatrics; ${ }^{3}$ Assistant Professor of Paediatrics,

Faculty of Medicine, Alexandria University, Alexandria, Egypt.

"Assistant Professor of Immunology, Medical Research Institute, Alexandria University, Alexandria, Egypt. sspeciallst in Patediatrics, El-Rami Hospital, Alexandria, Egypt.

Received: 05/08/97; accepted: 26/01/98

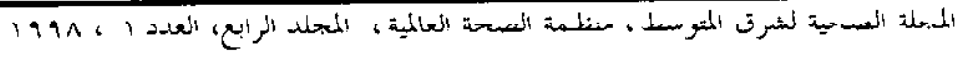




\section{Introduction}

Rheumatic fever (RF) continues to be a serious problem in developing countries. There is universal agreement that group A $\beta$-haemolytic streptococcal (GABS) pharyngitis is a prerequisite for the development of the initial and recurrent attacks of RF. However, the RF attack rate varies from $<0.3 \%$ following sporadic GABS pharyngitis in the general population to approximately $3 \%$ during epidemics of untreated severe exudative pharyngitis [I]. A study of the pattern of RF in Alexandria found that the majority of children with RF $(84 \%)$ had had their first attack between 4 and 12 years of age (mean age $9 \pm 3$ years). The same study also showed that $49.8 \%$ of the children presented with rheumatic carditis in their first attack of RF [2]. It is most likely that the pathogenetic mechanism for the development of RF after upper respiratory tract infection with GABS involves a combination of specific characteristics of the organism and some as yet undefined genetic predisposition in the human host [3].

The immunological basis of RF, although not fully elucidated, still stands as the most acceptable pathogenetic theory. Recent studies have shown a defective monocyte phagocytic system in children with $R F$, as well as in children with quiescent (inactive) rheumatic heart disease (RHD) as revealed by: chemiluminescence response of monocytes in children with acute RF and RHD [4], interleukin-1 release in children with acute RF [5], and monocyte yeast cell phagocytosis in rheumatic patients [6]. In a recent article, $\mathrm{Badr}$ El-Din suggested a possible scheme to explain the pathogenesis of RF on the basis that the primary susceptibility to RF is secondary to a defect in the monocyte phagocytic function [7]. During an untreated GABS infection, large amounts of strepto coccal antigens are absorbed by the host. In response to these, natural killer cells increase [8]. It is presumed that the latter, together with streptococcal products, expose or unmask the cross-reacting antigen binding sites in the heart and joints $[9,10]$. At the same time, cross-reacting antibodies and immune complexes (ICs) are formed. In a nonsusceptible child with a normal monocyte phagocytic system, these ICs are promptly phagocytosed. In the case of a susceptible individual with defective monocyte phagocytic activity, the ICs formed are not phagocytosed and will persist in the circulation, creating a sequence of events: first, a decrease in the suppressor T-cell population $[11,12]$ and second, heightened activity of helper T-cells. The result is excessive antibody production and the formation of ICs with free antibodybinding sites. These will circulate and bind to the exposed binding sites in the heart and joints, fixing the complement and causing acute inflammation [13].

The present work was conducted to study the monocyte phagocytic system, using chemiluminescence response, in children with quiescent RHD, their parents, their normal siblings and a control group of normal subjects who had no familial background of RF, in order to evaluate if the defective mononcyte phagocytic function can represent a genetic marker to rheumatic susceptibility and the possible mode of its inheritance.

\section{Subjects and methods}

\section{Subjects}

The study was conducted on 20 families of quiescent rheumatic children and on a control group including children and adults of nonrheumatic families. The families of quiescent rheumatic children included: 
- eight families, each having one child with quiescent RHD and one normal sibling;

- five families, each having one child with quiescent RHD and two normal siblings:

- one family with one quiescent RHD child and three normal siblings;

- two families: one family with two children with quiescent RHD and one normal sibling and the other with two children with quiescent RHD and no siblings;

- four families, each having one child with quiescent RHD and no siblings.

As regards parents, only 9 fathers and 17 mothers participated in the study. The other fathers and mothers" were missing on account of travel, death or business. Positive consanguinity (first cousins) between parents was found in $40 \%$ of the families studied. As controls, 25 healthy children and adults of nonrheumatic families participated in the study.

The subjects included were categorized into four groups.

Group I. Children with quiescent RHD, who attended the Alexandria University children's hospital. There were $22(10$ males and 12 females) and their ages ranged from 5 to 15 years (mean age 8.7 years). They included 16 cases of isolated mitral incompetence, 4 cases of isolated aortic incompetence and 2 cases of combined mitral and aortic incompetence. All had had a previous documented hospital admission for rheumatic carditis, according to the revised Jones criteria [3]. All patients were under prophylactic long-acting penicillin and were in a quiescent state as shown by their normal erythrocyte sedimentation rate $(E S R)(<10 \mathrm{~mm} / \mathrm{h})$ and normal antistreptolysin O (ASO) titre $(<250$ Todd units).
Group II. A total of 22 normal siblings (16 males and 6 females) with ages ranging from 5 to 15 years (mean age 9 years). They were all clinically free and had normal ESR and ASO titre. This group was further classified into two subgroups according to the results of chemiluminescence: Ila ( 7 children) with results comparable to normal controls and IIb (15 children) with significantly lower results than controls.

Group III. Parents of children with quiescent RHD. Only 9 fathers and 17 mothers ( 8 couples, one single father and 9 mothers) participated in the study. Other fathers and mothers were missing on account of travel, death or business. All were clinically free and had normal ESR and ASO titre.

Group IV. Normal controls from families with no history of RF or RHD. There were 25 with ages ranging from 12 to 35 years (mean age 20 years). Parents and children of both sexes were included. They were all clinically free and had normal ESR and ASO titre.

\section{Methods}

The following investigations were carried out for all subjects.

- Medical history was taken and clinical examination carried out with special emphasis on cardiac examination and exclusion of signs of rheumatic activity according to the Jones criteria [3].

- Laboratory tests were done to exclude rheumatic activity:

- ESR (Westergren method) [14]

- ASO titre determination by a rapid dilution technique [15].

- Phagocytic activity of monocytes was assessed using luminol-dependent chemiluminescence which entailed: 


\begin{tabular}{lccccc}
\hline Tabie 1 Count per minute unstimulated monocytes in all four groups & \\
\hline $\begin{array}{l}\text { Count } \\
\text { per } \\
\text { minute }\end{array}$ & $\begin{array}{c}\text { Group I } \\
\text { Children with } \\
\text { quiescent RHD } \\
(n=22)\end{array}$ & $\begin{array}{c}\text { Group II } \\
\text { Normal siblings of } \\
\text { patients with } \\
\text { quiescent RHD } \\
\text { IIb }(n=15)\end{array}$ & $\begin{array}{c}\text { Group III } \\
\text { Parents of children } \\
\text { with RHD }(n=26)\end{array}$ & $\begin{array}{c}\text { Normal controls from } \\
\text { nonrheumatic } \\
\text { families }(n=25)\end{array}$ \\
\hline Range & $3457-4960$ & $3469-3941$ & $2868-3660$ & $2126-3652$ & $2659-4677$ \\
Mean & 4104.73 & 3707.8 & 3250.2 & 3027.08 & 3669.64 \\
$s$ & 443.1 & 205.9 & 248.6 & 386.1 & 438.7 \\
\hline
\end{tabular}

$\mathrm{t}$-test: significant differences at $\mathrm{P}=0.01$ were obtained between: group / and all other groups; group lla and groups I, Ib and I/: group I/B and groups I, Ha and IV; group III and groups I, Ila, IV

$\mathbf{s}=$ standard deviation

- Isolation of blood monocytes $[16,17,18]$

- Chemiluminescence where emitted light was measured by appropriate fluorometric detection $[19,20]$. The sensitivity of the assay was increased by using luminol, which acts as a substrate for oxygen. The vials were incubated with and without zymosan solution (stimulant agent), After these additions, the cells were incubated for 15 minutes. The vials were counted in the dark in a scintillation counter ( $\beta$ counter). Chemiluminescence levels peak at around $10 \mathrm{~min}$ utes. The count per minute (CPM) taken in this work was that observed in the 10th minute.

\section{Results}

All group I patients suffered from RHD; 16 had isolated mitral incompetence, 4 had isolated aortic incompetence and 2 suffered from combined mitral and aortic incompetence. The absence of rheumatic activity in group 1 patients was confirmed according to modified Jones criteria, including normal ESR (all patients had ESR $<10 \mathrm{~mm} / \mathrm{h}$ ) and the absence of recent streptococcal infection (ASO titre $<250$ Todd units). Normal ESR and ASO values were also obtained for all other groups of children and parents.

Table ] illustrates the range and mean values of CPM of unstimulated monocytes in the four groups. Group II children had been further classified into two subgroups according to their CPM readings. Subgroup Ila included 7 normal siblings (one-third of the siblings) who had a mean CPM that was not significantly different from that of the controls. Subgroup Ilb, on the other hand, included 15 normal siblings (two-thirds of the siblings) who had a mean CPM significantly lower than the controls.

Table I shows that, at $\mathrm{P}<0.01$, group I patients had significantly higher CPM than all other groups $(t=3.2,7.5,8.9$ and 3.4 for comparison between group I and groups IIa, IIb, III and IV respectively). Group Ila gave readings comparable to group IV $(t=0.33)$ but significantly higher than groups IIb $(t=4.5)$ and III $(t=6.3)$. Group III had the lowest CPM values

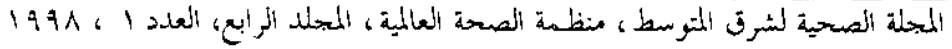




\begin{tabular}{|c|c|c|c|c|c|}
\hline \multirow[t]{2}{*}{$\begin{array}{l}\text { Count } \\
\text { por } \\
\text { minute }\end{array}$} & \multirow[t]{2}{*}{$\begin{array}{c}\text { Group I } \\
\text { Childron with } \\
\text { quiescent RHD } \\
(n=22)\end{array}$} & \multicolumn{2}{|c|}{$\begin{array}{c}\text { Group II } \\
\text { Normal siblings of } \\
\text { patients with } \\
\text { quiescent RHD }\end{array}$} & \multirow[t]{2}{*}{$\begin{array}{l}\text { Group III } \\
\text { Paronte of childron } \\
\text { with RHD }(n=26)\end{array}$} & \multirow[t]{2}{*}{$\begin{array}{c}\text { Group IV } \\
\text { Normal controls from } \\
\text { nonrheumatic } \\
\text { families }(n=25)\end{array}$} \\
\hline & & Ila $(n=7)$ & Ilb $(n=15)$ & & \\
\hline Range & $10975-23679$ & $55264-67510$ & $40861-53988$ & $345502-59164$ & $54420-75246$ \\
\hline Mean & 15695.1 & 59608.9 & 48459 & 51317 & 64573.04 \\
\hline$s$ & 3711.77 & 4868.9 & 3785.4 & 4432.4 & 3863.7 \\
\hline
\end{tabular}

$\mathrm{t}$-test: significant differences at $\mathrm{P}=0.01$ were obtained between: group / and all other groups; group lla and groups I, IIb and III; group I/b and groups I, IIa and $\mathrm{V}$; group III and groups I, IIa and $\mathrm{V}$

$\mathrm{s}=$ standard deviation

which were significantly lower than those of groups I, IJa, and IV $(t=8.9,6.3$ and 5.5 respectively).

Table 2 shows the range and mean values of CPM of monocytes after stimulation with zymosan. The highest mean CPM was in group IV, tollowed by groups IIa, III, and IIb, while the lowest mean CPM was in group I where there was a significantly lower mean value than all other groups $(t=$ $21.9,26.9,30.3$ and 44.2 , comparing group I with groups IIa, IIb, III and IV respectively). Group IIa values were comparable to those of group IV $(t=2.4)$ but significantly higher than groups IIb $(t=5.4)$ and III $(t=$ 4.1). On the other hand, the mean CPM of group IIb was comparable to that of group III $(t=2.1)$ but significantly lower than groups Ila $(t=5.4)$ and IV $(t=12.9)$. The CPM of group III was significantly lower than that of group IV ( $t=11.4$ ) but still significantly higher than that of group I $(t=$ 30.3).

\section{Discussion}

So far, researchers have not yet agreed upon a particular mode of inheritance for
RF. That a single autosomal recessive gene determines susceptibility to RF is the theory proposed by Wilson et al. [21] and corroborated by Rajapakse et al. [22]. Wilson et al. examined 112 families and found close agreement between the observed and expected values except for the offspring of parents who both had RF where, under a recessive hypothesis, all should be affected. Wilson and Schweitzer [23] reported the results of a further study on the inheritance of RF giving support to their previous conclusion of a recessive inheritance. This study is particularly interesting since it began with selected parents rather than selected children. The observations are therefore more readily interpreted.

Analysis of our results could favour an autosomal recessive pattem of inherltance. Analysis of the results of Table 1 shows that before stimulation with zymosan:

- The mean CPM was significantly higher in children with quiescent RHD than in all other groups. This may be due to prior stimulation by streptococcal antigens. This is in agreement with Kumar et al. $[24$ ], who studied the generation of oxygen free radicals by peripheral blood monocytes and neutrophils of pa- 
tients with $\mathrm{RF}$ and RHD using an enhanced chemiluminescence technique. Their study included five groups: acute $R F$, recurrence of rheumatic activity, chronic RHD, acute pharyngitis and normal controls. The chemiluminescence was measured in response to streptococcal membrane antigen, carbohydrate antigen and latex as triggering agents. Chemiluminescent response of monocytes and neutrophils was significantly higher in acute RF and recurrence of RHD as compared with patients with acute pharyngitis and chronic RHD

- The mean CPM in group IV was significantly higher than in group III (parents) who are assumed to be heterozygous.

- The mean CPM in group IV was significantly higher than that in subgroup IIb (Iwo-thlrds of siblings) who are assumed to be heterozygous.

- There was no significant difference between group IV and subgroup Ila (onethird of siblings) who are assumed to be homozygous normal.

These findings are evidence of an autosomal pattern of inheritance. After stimulation by zymosan, analysis of the results in Table 2 shows that:

- The mean CPM of group I (children with quiescent RHD) was significantly lower than all other groups, suggesting that they are homozygous for a mutant gene(s) responsible for the defective. function of the monocyte phagocytic system.

- The mean CPM in parents (group III) was significantly higher than in group I but significantly lower than the control group IV, suggesting again that parents are heterozygous for the mutant gene(s).
- The mean CPM of subgroup IIa (onethird of siblings) was not significantly different from the level of control cases, suggesting again that they are homozygous normal.

- The levels in subgroup IIb (two-thirds of siblings) were significantly lower than subgroup IIa while there was no significant difference from parents suggesting that both parents and two-thirds of siblings are heterozygous.

From these results one can conclude the following:

- Children with RHD are homozygous for the mutant gene(s).

- One-third of normal siblings are homozygous normal.

- Two-thirds of normal siblings are heterozygous.

- Parents are considered to be heterozygous.

According to this theory of recessive inlueritance, the offspring of parents who both have RF should all be susceptible but not necessarily affected because the eventual development of $R F$ depends on exposure to streptococcal infection. They may be less frequently exposed to streptococcal infection and/or more promptly treated because of parental anxiety.

In conclusion, one can propose that the genetic susceptibility lo RF follows an autosomal recessive inheritance of a defect(s) in the mononcyte phagocytic function. The latter can, lherefore, represent a genetic marker for rheumatic susceptibility. 


\section{References}

1. Markowite M. Rheuriatic fever, Irt: Behrman RE, Vaughan VC, eds. Nelson textbook of pediatrics, 12th ed. Philadelphia, WE Saunders Company, 1983:588.

2. Kassem AS et al. The pattern of rheumatic fever in Alexandria with a 10-year follow-up of the valvular lesions. Gazette of the Egyptian Pediatric Association, 1982, 30:69-74.

3. Kaplan EL. Rheumatic fever. In: Behrman RE et al. eds. Nelson textbook of pediatrics, 14 th ed. Philadelphia, WB Saunders Company, 1992:640-6.

4. Badr EI-Din MK et al. Chemiluminescence response of monocytes in children with acute rheumatic fever and rheumatic heart disease. Alexandria journal of pediatrics, 1994, 8:375-9.

5. Hammad FI. Study of interleukin-1 release in children with acute rheumatic fever [Thesis]. Alexandria University, Alexandria, Egypt, 1993.

6. Kassem AS et al. Monocyte yeast cell phagocytosis and serum opsonic activity in children with rheumatic heart disease. Alexandria journal of pediatrics, 1995 , 9:353-7.

7. Badr El-Din MK. Solving the problem of the pathogenesis of rheumatic fever. $A n-$ nals of tropical pediatrics, 1996 , $16(2): 113-21$.

8. El-Araby $\mid$ et al. Study of the cytotoxic activity produced by natural killor colls in cases of active rheumatic fever. Alexandria joumal of pediatrics, 1994, 8:311-7.

9. Zabriskie JB, Frledman JE. The role of heart binding antibodies in rheumatic fever. Advances in experimental medicine and brology, 1983, 161:457-70.

10. Williams $\mathrm{RC}$ et al. Circulating immune complexes in acute rheumatic fever.
Jourral of cifrical and laboralory inmmnology, 1979, 2:185-90.

11. Etzioni $A B$ et al. Transient immuno-regulatory perturbation during the acute phase of rheumatic fever. Joumal of clinical and laboratory immunology, 1986, 20(1):7-9.

12. Eissa $A M$ et al. Circulating immune complexes and complement in some Egyptian rheumatic heart subjects. Joumal of the Arab child, 1990, 1:7-13.

13. Anand IS. Ganguly NK. Bidawi PS. Circulating immune complexes in rheumatic heart disease. Indian journal of medical research, 1982, 76:430-5.

14. Dacie JV, Lewis SM. Practical haematology, 5th ed. London, Churchill Livingstone, 1975:21-34, 580-3.

15. Fimara AS. A rapid dilution technique for the ASO titer. American journal of clinical pathology; 1972, 57:538-40.

16. Perper RJ, Zee TU, Mickelson MM. Purification of lymphocyte and platelet by gradlent centrifugation. Journal of laboratory and clinical medicine, 1968. 72:842-9.

17. Mizel SB. Production and quantitation of lymphocyte activating factor (interleukin1). In: Manual of macrophage methodolugy. New rork, Marcel Decker, 1981:423-9.

18. Boyum A. Separation of leukocytes from blood and bone marrow. Introduction. Scandinavian journal of clinical and laboratory investigation, 1968, 97 (suppl.):7.

19. Cheson BD et al. The origin of the chemiluminescence of phagocytosing granulocytes. Journal of clinical investigation, 1976, 58:789-96.

20. Pick $E$, Keisari Y. A simple colorimetric method for the measurement of hydro- 
gen peroxide produced by cells in culture. Journal of immunological methods, $1980,38: 161-70$.

21. Wilson MG, Schweitzer MD, Lubschez R. The familial epidemiology of rheumatic fever: genetic and epidemiological studies. Journal of pediatrics, 1943, 22:468, 581.

22. Rajapakse CAN, Halim K, Al-Orainey I. A genetic marker for rheumatic heart disease. British heart journal, 1987 , 58:659-62.
23. Wilson MG, Schweitzer MD. Pattern of hereditary susceptibility in rheumatic fever. Circulation, 1954, 10:699.

24. Kumar $V$ et al. Role of oxygen free radicals generated by blood monocytes and neutrophils in the pathogenesis of rheumatic fever and rheumatic heart disease. Journal of molecular and cellular cardiol$o g y, 1990,22: 645-51$.

At least 12 million people are estimated to be currently affected by RF/RHD. More than 2 million require repeated hospital admission, and one million will need heart surgery in the next 5-20 years.

Although there is, as yet, no available safe and effective antirheumatic streptococcal vaccine or genetic marker to identify people at high risk of developing RF, there are proven, cost-effective methods for the secondary and primary prevention of RF/RHD. Effective methods also exist for the diagnosis and treatment of acute attacks of RF, as do clinical and surgical methods for the palliative care of RHD and for its rehabilitation.

Sonrce: The World Health Report, 1097. World Hoalth Orgamization, Geneva.

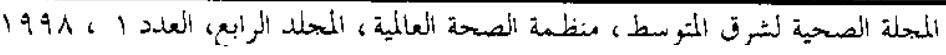

